lias always been that all officers must enter the "General Duties Branch", and devote their time to a complote training in flying for, at least, many years of their timo as junior officers. Later they can express $\Omega$ wish to take up specialization in technical work, but they are still required to maintain proficiency in flying. Thus the process of becoming a technical specialist is a slow one, and in a service in which the retiring ago is, possibly necessarily, set fairly early, as flying is primarily a young man's job, the officer choosing these branches alwrys finds himself at a disadvantage, either for promotion within the service, or in respect of his ability to obtain employment in the technical side of aviation upon retirement. Also the break in continuity of training and accumulation of experience is usually considered to $b a$ unwise, and many young engineers, both from the universities and works apprenticeships, have undoubtedly been deterred from entering the Royal Air Force by this reason.

Is spite of the enthusiastic membership of the university air squadrons the number of technical graduates offering themselves for University Commissions in the Royal Air Force has always been relatively small. The new branch should removo these disadvantages. Lntrants for commissions aro now offered direct entry into technical work, without having to spend several years in acquiring proficiency in flying. Thoy are to be recruited from university graduates in engineering or natural science, and student apprentices from works who have acquired theoretical knowledgo up to $\mathrm{n}$ university degree standard. The retiring age limit may well now be extended, ns the work is not that in which the younger man necessarily excels, in fact the older man would bo superior by reason of his accumu. lated experienco. Prospects of promotion should also now be greater as there must bo senior adminis. trative posts within the new department.

\section{Further Archæological Excavation in Syria}

Sir LeONard Wooldex's third season of excavation on the ancient site of Allalakh at Atchana near Antioch, as anticipated, has enlarged and added further detail to the picture of a great meeting place of the civilizations of East and West at an entrance gato to western Asin; but at its close it held out promise of an even greater field of discovery still to be explored. Of this a glimpso may be afforded when the numerous cunciform inscriptions retrieved in the season just past have been submitted to inspection. Sir Leonard in his preliminary report (The T'imes, August 2 and 3) opened with an account of the further excavation of the earlier palace, which preceded that of the fifteenth-century Hittite king, Nig-me-pa. This earlier building, cannot, Sir Leonard thinks, bo much later than tho timo of Inmmurabi, and he assigns it tentatively to the eighteenth century 3.c. Tho structural features, which point to its use in part for administrative and business purposes, in part as a royal residence, convey the impression of a sense of dignity and propriety, com- bined with an unusual appreciation of space and air, particularly noticeable in the arrangement of the upper residential chambers, with a loggia giving an extensive view over the city, and an approach by newel stairs, of which the first two flights aro nearly perfectly preserved. It was, however, from a private house of the fifteenth century that the much desired further evidence was obtained of the contact with Crete, for which mainly the excavation of Atchana wus undertaken. This now took the form of a fresco, which is exactly similar to a schems of decoration found at Knossos, and a 12.wick lamp in red porphyry in the form of the capital of a column, which at Knossos woukl be hailed, Sir Leonard says, as a typical, but unusually fine, example of Minoan art.

Ir was, however, towards the close of tho season's work that the most striking discovery was made, which, as Sir Leonard says, "goes far to completo the picture of the ancient city of Allalaklı". 'This was a temple, which throws light upon the religion of the people, and gives cxamples of their major arts. Though the clearance of this part of the site has only just begun, it is already evident that here are the superimposed remains of at least four temples, of which tho latest may dato to about 1200 B.c. and the earliest to the fifteenth century. They had been richly adorned with sculpturo. Although as yet it has not been possiblo for Sir Leonard to give more than the most summary of accounts, the record of finds is amazing in both number and interest. Among the moro arresting finds are the remarkable sculptured lions, the bronze spearhead, decmed to bo a cult object, and most remarkable of all, the hidden statuo of a king or god in white limestone with its fifty lines of cuneiform inseription, of which the decipherment will bo awaited with keenest anticipation. Such a mass of evidence of the character of Hittite art, and of so early a date-at least of 1200 B.c. and possibly oven of the fifteenth century-is indeed an unoxpected, but more than welcome find.

\section{Excavations at Ezion-Geber}

REcest excavation at Tell el-Kheleifi on the Gulf of Aqabah, Sinai, by the American School of Oriontal Research at Jerusalem, not only hrs confirmed tho indications of the importance of this site in early times as a meeting place of a number of trado routes, afforded by investigations in 1938, but also has revealed that it was the centro of an oxtensivo industry for the smelting and refining of copper and iron from the mines of the adjacent Arabah. The site has been identified with tho great port of King Solomon, Ezion-Geber "which is by Elath on the shore of the Red Sea, in the land of Fdom". No longer, however, does it stand by the sea. Tho prevailing northerly winds have brought sand to silt up the head of the gulf, so that the shore is now half a mile away. The importance of the city as a commercial centro was indicated in the first season's excavation by a number of finds, of which tho most important is held to bo n large broken jar, on which 